\title{
Hvordan møte det utenkelige - Utøya 22. juli 2011
}

\author{
Hole er en liten kommune i Buskerud. Med sin vakre natur, sin rike kulturarv og sin tradisjon for åpenhet \\ og omsorg blant kommunens innbyggere, er dette blitt en attraktiv kommune både å bosette seg i \\ og tilbringe fritid i. I dette bildet har AUFs sommerleirer på Utøya vært en kjær og velkommen del \\ av kommunens historie.
}

22. juli skjedde noe som ingen var forberedt på, eller hadde fasitsvar på hvordan man skulle møte. Hendelsene i Oslo og på Utøya var så ubegripelig grusomme på flere plan. Det var lidelser og skjebner som vi nesten ikke er i stand til å klare å ta inn over oss. Det var en katastrofe av veldige dimensjoner, og behovet for umiddelbar helsemessig krisehjelp var enormt.

Som kommunelege 1 i Hole kommune fikk jeg rollen som operativ helseleder for situasjonen som oppsto. Dette innbefattet en lederrolle opp mot operativ leder innen politiet og Kripos. I tillegg skulle jeg opptre som leder for tilbudet kommunen skulle gi, ifølge prinsippet om «nødvendig og forsvarlig helsetilbud» etter kommunehelseloven. Kommunelegen i nabokommunen Ringerike bidro hele veien som min «høyre hånd». Hole kommunes kriseteam og beredskapsteam ble umiddelbart aktivert, og beredskapsplaner ble forsøkt fulgt. Kommunen hadde trent på mye - alt fra pandemier til trafikkulykkescenarier og naturkatastrofer - men noe slikt som skjedde 22. juli, hadde ingen trent på. Raskt gikk situasjonen fra en kommunal til en nasjonal katastrofe. Nasjonalt var man heller ikke forberedt på noe slikt. Norge har ikke opplevd noe tilsvarende siden annen verdenskrig. Læringskurven var derfor bratt.

\section{Hjelpen settes i gang}

Ettersom AMK hadde den koordinerende rollen med å sørge for at de fysisk skadede ble transportert til rette behandlende instans, var rollen vår på skadestedet å se til at vi fikk utplassert tilstrekkelig med leger som kunne yte akutt nødhjelp, samt vurdere hvor pasienten skulle videre i behandlingskjeden. Hjelpekjeden, fra frivillige hjelpere og organisasjoner til lokalt akuttmedisinsk personale og ulike involverte sykehus, virket å være operativ og fungerende.

Deres helhjertede innsats var unik og avgjørende for det arbeidet som ble gjort for de mange skadede.

Vi begynte raskt å etablere og drifte et mottak for overlevende og pårørende med søkelys på psykososial krisehjelp i trygge rammer. Vi valgte å spørre Sundvolden Hotel om hjelp. Dette viste seg i ettertid å være et helt avgjørende valg for å kunne yte hjelpen i det omfanget vi etter hvert måtte gi. Hadde vi forsøkt det samme på en lokal skole eller liknende, hadde det neppe fungert tilfredsstillende. Initialt gikk hjelpen ut på å ta hånd om våte og forfrosne ungdommer med akutte krisereaksjoner. Hotellets senger ble strippet for dyner, lokale klesbutikker stilte med tøy, ulike organisasjoner stilte med tepper, og atskillige frivillige bidro med det de kunne. Psykologer og leger som vi kontaktet, kom for å bistå. Mange frivillige psykologer og annet medisinsk personale møtte i tillegg opp på døren med ønske om å delta. Sykehuset stilte med anestesilege og kirurg for å kvalitetssikre at folk på Sundvolden fikk nødvendig akutthjelp. Mat ble servert, ungdommene registrert og deretter innlosjert på rom for å ha mulighet til å hvile. Den medisinske psykososiale tjenesten fungerte kontinuerlig, dels på merkede baser og dels oppsøkende blant ungdommene på hotellet. Både individuelle samtaler og gruppesamtaler ble gitt. Pårørendetelefon betjent av medisinsk personale ble opprettet på hotellet. Det ble en intens natt.

\section{Dagen etter}

Om morgenen 23. juli hadde vi bedt ca. 20 personer om komme, inkludert prest, imam, psykologer, sykepleier, leger m.m. Cirka 40 personer dukket opp, og alle ville hjelpe. Derfor opprettet vi et eget selvgående team som laget og koordinerte vaktlister i tre skift med hjelpearbeidere gjennom døgnet. Pårørende strømmet til. Omfanget av det hele veltet inn over oss. Informasjon med tall på skadede og savnede utløste krisereaksjoner og fortvilelse. Det psykososiale tilbudet ble derfor stadig viktigere. Overlevende ungdommer ble løpende avhørt av politiet. Utover dagen reiste de fleste overlevende hjem med sine familier. De gjenværende ble nå i stor grad pårørende som savnet sine. Politiet og Kripos startet identifiseringsarbeidet og jobbet med oversikt og etterforskning. Det ble avholdt fellesmøter for de pårørende flere ganger daglig, for å få gitt informasjon. Både politi og helsevesen bidro. Utpå dagen kom et team fra Kongsberg som laget et journalsystem som alle kunne bruke, inkludert leger, prester og psykologer, og dette ble koblet mot en database for savnede, overlevende og etter hvert pårørende.

\section{De tre neste dagene}

Dag tre og fire ble en videreføring av dag to, der politiet jobbet videre med identifisering. Behovet for psykososialt tilbud til de pårørende vedvarte. Trykket fra tilstede- værende medier begynte å avta. All informasjon fra helsetjenesten på Sundvolden gikk hele perioden via ordfører eller politiets informasjonstjeneste. Nytt var at det ble opprettet et team for å bistå «båtfolket» fra Utøya camping og andre involverte.

Dag fem ble tilbudet fra Sundvolden hotel avsluttet og overført til Rikshospitalets pasienthotell, som overtok journalsystemet. Sundvolden ble dermed tømt for pårørende, og neste fase ble nå debriefing av helsepersonell på stedet. Vi følte et klart behov for dette, men det viste seg overraskende vanskelig å vinne gehør for dette oppover i systemet. Et team ledet av Anders Smith og Atle Dyregrov gjennomførte imidlertid en god debriefing i puljer over to dager.

\section{Tid for å lære}

Alt $i$ alt bidro over 250 personer fra ulike yrkesgrupper til å få til et forsvarlig helsemessig krisetilbud etter Utøya-katastrofen. En liten, fredelig kommune som Hole hadde ikke alle nødvendige ressurser selv og var helt avhengig av hjelp. Det fikk vi. En katastrofe av slike dimensjoner var ingen forberedt på.

Vi må nå lære av hvordan vi møtte hendelsen, både hva som fungerte godt, og hva som fungerte mindre godt. Dette jobber vi med, vel vitende om at det vil ta tid. Likevel sitter vi igjen med en følelse av at når noe så grusomt skjer, er det på sitt vis godt å kunne være med å hjelpe. All frivillig innsats viste dette, og det er noe alle er takknemlige for. Alt $i$ alt var det dermed et privilegium å få lov til å lede en slik hjelpeinnsats - selv om jeg skulle ønske at det aldri hadde vært behov for den.

\section{Bernt Ivar Gaarder}

bernt_gaarder@hotmail.com

Hole kommune

Bernt Ivar Gaarder (f. 1970) er fastlege ved Hole medisinske senter og kommunelege 1 i Hole kommune.

Ingen oppgitte interessekonflikter.

Mottatt 30.8. 2011 og godkjent 30.8. 2011

Medisinsk redaktør Erlend Hem. 